\title{
PENGARUH PENDIDIKAN SEBAYA TERHADAP PENGETAHUAN KESEHATAN REPODUKSI REMAJA DI KARANG TARUNA KABUPATEN BANYUWANGI
}

\author{
Septa Indra Puspikawati ${ }^{1}$, Hario Megatsari ${ }^{2}$ \\ ${ }^{1}$ Departemen Gizi Kesehatan Masyarakat, Program Studi S1 Kesehatan Masyarakat, PSDKU UNAIR di \\ Banyuwangi \\ ${ }^{2}$ Departemen Promosi Kesehatan dan Ilmu Perilaku, Fakultas Kesehatan Masyarakat, Universitas Airlangga \\ septaindra@fkm.unair.ac.id
}

\begin{abstract}
In 2014, early marriage in Banyuwangi as much as $22 \%$ of the number of married couples. One reason is the lack of knowledge about reproductive health. Effective efforts to increase knowledge can be made through peer education. This study aims to determine the effect of peer education on adolescent reproductive health knowledge. This type of research is experimental and research design is quasi experiment pre-post with controls design. The research was conducted on youth of Tamansari, Licin, Banyuwangi in 2015. Subjects in this study were chosen by convenient sampling and divided into two groups, namely teenage youth who received peer education (13 people) and youth who do not receive peer education (17 people). The results showed that the majority of participants in the treatment group were female $(76,92 \%)$, while the control group male sex (56,25\%). The average age in both groups was 17 years old and high education $(76,92 \%$ and $56.25 \%)$, there is a difference of knowledge before and after treatment between the case and control groups $(p=0,04$ and $p=0,00)$. Knowledge before and after the case and control groups were also different $(p=0,04$ and $p=0,01)$. So, there is a difference of knowledge before and after treatment between the treatment and control groups but no effect of education on knowledge improvement.

Keywords: adolescent, knowledge, peer education, reproductive health
\end{abstract}

\begin{abstract}
ABSTRAK
Pada tahun 2014, pernikahan dini di Banyuwangi sebanyak 22\% dari jumlah pasangan yang menikah. Salah satu penyebabnya adalah kurangnya pengetahuan tentang kesehatan reproduksi. Upaya peningkatan pengetahuan yang efektif dapat dilakukan melalui pendidikan sebaya. Penelitian ini bertujuan mengetahui pengaruh pendidikan sebaya terhadap pengetahuan kesehatan reproduksi remaja. Jenis penelitian adalah eksperimen dengan desain penelitian quasi eksperimeni pre-post with kontrol design. Penelitian dilakukan pada remaja karang taruna Tamansari, Licin, Banyuwangi tahun 2015. Subjek dalam penelitian ini dipilih secara convenient sampling dan terbagi dalam dua grup yaitu remaja karang taruna yang mendapat pendidikan sebaya (13 orang) dan remaja yang tidak mendapat pendidikan sebaya (17 orang). Hasil penelitian menunjukkan bahwa sebagian peserta pada kelompok perlakuan berjenis kelamin perempuan $(76,92 \%)$ sedangkan pada kelompok kontrol berjenis kelamin laki-laki (56,25\%). Rata-rata umur pada kedua kelompok adalah 17 tahun dan berpendidikan tinggi $(76,92 \%$ dan 56,25\%), terdapat perbedaan pengetahuan sebelum dan sesudah perlakuan antara kelompok kasus dan kontrol $(\mathrm{p}=0,04$ dan $\mathrm{p}=0,001)$. Pengetahuan sebelum dan sesudah pada kelompok kasus dan kontrol juga berbeda $(\mathrm{p}=0,04$ dan $\mathrm{p}=0,01)$. Sehingga ada perbedaan pengetahuan sebelum dan sesudah perlakuan antara kelompok perlakuan dan kontrol namun tidak ada pengaruh pendidikan pada peningkatan pengetahuan.
\end{abstract}

Kata kunci: kesehatan reproduksi, pendidikan sebaya, pengetahuan, remaja 
Septa, et al. Pengaruh Pendidikan Sebaya Terhadap Pengetahuan Kesehatan Reproduksi Remaja di Karang Taruna Kabupaten Banyuwangi

\section{PENDAHULUAN}

Banyuwangi memiliki citra sebagai daerah klenik dan terbelakang, tetapi sekarang Banyuwangi mulai berubah sebagai daerah yang terus berinovasi dalam pembangunan. Pembangunan dilakukan dibeberapa sektor diantaranya ekonomi, pendidikan, infrastruktur, budaya dan pariwisata. Salah satu tempat wisata yang sedang dikembangkan dan dipromosikan oleh pemerintah Banyuwangi adalah Gunung Ijen. Tempat tersebut sering dijadikan untuk event, diantaranya Tour de Ijen (sekarang berubah nama 'International Tour de Banyuwangi Ijen') dan Jazz Ijen Banyuwangi (Pemkab Banyuwangi, 2015). Keberadaan Gunung Ijen tersebut bermanfaat untuk mendongkrak pendapatan domestik sehingga kesejahteraan akan terdistribusi (Kecamatan Licin, 2014). Disisi lain berkembangnya Gunung Ijen dapat memberikan dampak negatif, diantaranya adalah munculnya premanisme dan pergaulan bebas. Kelompok masyarakat yang rentaan terhadap masalah tersebut adalah remaja. Hasil penelitian Zumala dan Alika (2014) menunjukkan bahwa tempat wisata menjadi tempat berpacaran untuk remaja dengan perilaku berpacaran yang mengawatirkan.

Perilaku berpacaran tersebut dapat menjadi pergaulan bebas yang mengarah ke seks bebas. Data Riskesdas tahun 2010 menunjukkan bahwa $4 \%$ remaja perempuan dan $2,2 \%$ remaja laki-laki usia 14 tahun telah melakukan hubungan seksual sebelum menikah (Kemenkes RI, 2010). Hal ini diperkuat dengan data Survei Kesehatan Reproduksi Republik Indonesia (SKRRI) pada tahun 2007 yang menunjukkan bahwa $22,6 \%$ remaja perempuan dan $18,6 \%$ remaja laki-laki berpacaran pertama kali pada usia 12 hingga 14 tahun (Badan Pusat Statistik dan Macro International, 2007). Data Riskedas tahun 2013 juga menunjukkan bahwa sebanyak 2,6\% perempuan berusia 10-54 tahun menikah pertama kali pada umur kurang dari 15 tahun dan 23,9\% menikah pada umur 15-19 tahun (Kementerian Kesehatan Republik Indonesia, 2013). Pada tahun 2014, angka penikahan dini di Banyuwangi sebesar 22\% (BPPKB Banyuwangi, 2015). Perilaku seks bebas saat ini menjadi tren dan tersebar secara merata di seluruh kota dan desa, dan terjadi. pada berbagai golongan status ekonomi dan sosial, baik kaya maupun miskin.
JPH RECODE Maret 2018; 1 (2) : 80:88 http://e-journal.unair.ac.id/JPHRECODE

Hasil Survei Demografi dan Kesehatan Indonesia tahun 2012 (Kemenkes RI, 2012) menunjukkan bahwa angka fertilitas remaja 1519 tahun di pedesaan dua kali lipat dari daerah perkotaan.

Masalah tersebut muncul sebagai akibat dari kurangnya pengetahuan remaja akan masalah kesehatan reproduksi dan perilaku seksualitas yang benar. Hasil SDKI 2012 menunjukkan bahwa tingkat pengetahuan mengenai tanda-tanda pubertas lebih banyak diketahui oleh perempuan. Hasil penelitian menunjukkan bahwa $20 \%$ remaja pria dan $5 \%$ remaja wanita tidak mampu menyebutkan tandatanda pubertas pada seorang wanita. Baseline survey yang dilakukan oleh BKKBN dan Universitas Indonesia pada tahun 1999 antara lain memperlihatkan bahwa responden yang mengetahui dengan benar mengenai proses kehamilan hanya 55\% (Badan Kependudukan dan Keluarga Berencana Nasional, 1999). Padahal dilain pihak saat ini remaja (baik di daerah perdesaan maupun perkotaan) lebih toleran dengan hubungan seks sebelum menikah . Hasil SDKI 2012 juga menunjukkan bahwa sebanyak 40,2\% remaja (15-24 tahun) tidak mengetahui usia ideal untuk wanita memiliki anak. yang Penelitian Aryani menyatakan bahwa pengetahuan remaja tentang kesehatan reproduksi sangat rendah yaitu sekitar $75 \%$ (Aryani, 2010). Hasil penelitian Zumala dan Alika (2014) menunjukkan bahwa pengetahuan santri tentang reproduksi sudah benar namun masih tumpang tindih dengan organ reproduksi. Dalam penelitian tersebut juga diketahui bahwa ada santri yang memiliki pemahaman yang keliru tentang seksualitas.

Informasi yang benar mengenai proses reproduksi harus diketahui dengan benar oleh remaja, remaja juga harus mengetahui berbagai faktor yang berhubungan dengan kesehatan reproduksi sehingga mereka memiliki sikap dan tingkah laku yang bertanggung jawab mengenai proses reproduksi (Presiden Republik Indonesia, 2009). Upaya penyampaian informasi dan perubahan perilaku tersebut dapat dilakukan melalui pendidikan sebaya atau peer education. Data SKRRI tahun 2007 menyatakan bahwa sebanyak $69,3 \%$ remaja perempuan dan $56,7 \%$ remaja laki-laki mendapatkan informasi mengenai kesehatan reproduksi dari teman 
Septa, et al. Pengaruh Pendidikan Sebaya Terhadap Pengetahuan Kesehatan Reproduksi Remaja di Karang Taruna Kabupaten Banyuwangi

(Badan Pusat Statistik dan Macro International, 2007). Aisah et al (2010) menyatakan bahwa pendidikan sebaya merupakan metode yang efektif untuk peningkatan pengetahuan, perubahan sikap dan keterampilan dalam pencegahan anemeia besi.

Pendidikan sebaya dapat dilakukan di dalam maupun di luar sekolah. Pendidikan sebaya diluar sekolah dipandang lebih efektif daripada di dalam sekolah. Pendidikan sebaya di luar sekolah dapat memanfaatkan struktur formal maupun informal yang ada di masyarakat seperti asrama, pesantren, sanggar tari dan karang taruna. Desa Tamansari memiliki organisasi karang taruna yang kegiatanya belum optimal. Organisasi tersebut dapat dimanfaatkan sebagai media promosi kesehatan berbasis komunitas (community center based) bagi remaja, remaja dilibatkan secara aktif dalam upaya tersebut. Oleh karena itu penelitian ini bertujuan untuk mengetahui pengaruh pendidikan sebaya terhadap pengetahuan kesehatan reproduksi pada remaja karang taruna Desa Tamansari.
JPH RECODE Maret 2018; 1 (2) : 80:88 http://e-journal.unair.ac.id/JPHRECODE

Jenis penelitian adalah eksperimen dengan desain penelitian quasi eksperiment pre-post with kontrol design. Penelitian ini dilakukan di Desa Tamansari Kecamatan Licin Kabupaten Banyuwangi pada bulan September-November 2015 dengan populasi penelitian adalah semua remaja karang taruna di Desa Tamansari Kecamatan Licin berjumlah 126 orang. Sampel minimal berdasarkan hasil perhitungan menggunakan rumus Lameshow et al (1997) adalah 13 sampel per kelompok sehingga total sampel 26 orang yang dipilih secara convenient sampling. Kriteria inklusi (kasus dan kontrol) yaitu remaja karang taruna Desa Licin, mampu membaca dan menulis, sehat jasmani dan rohani, belum pernah mendapatkan pendidikan sebaya, dan bersedia ikut dalam penelitian. Subjek dalam penelitian ini terbagi dalam dua grup yaitu remaja karang taruna yang mendapat pendidikan sebaya dan remaja yang tidak mendapat pendidikan sebaya. Rancangan ekperimen dalam penelitian ini adalah:

\section{METODE}

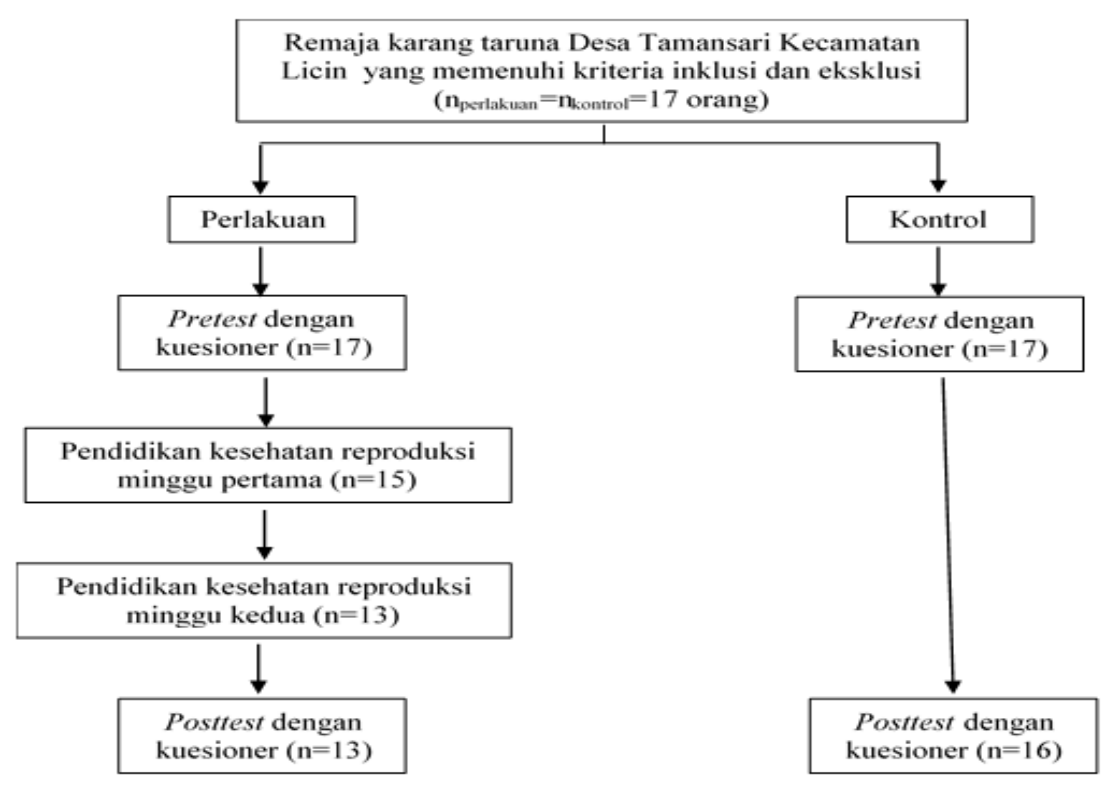

Grup 1 $\mathrm{O}_{1} \longrightarrow \mathrm{T} \longrightarrow \mathrm{O}_{2}$

Grup $2 \quad \mathrm{O}_{1} \longrightarrow \mathrm{O}_{2}$

Keterangan:

$\mathrm{O}_{1}$ : Pengetahuan kesehatan reproduksi sebelum pendidikan sebaya 
$\mathrm{O}_{2}$ : Pengetahuan kesehatan reproduksi setelah pendidikan sebaya

$\mathrm{T}$ : Perlakuan pendidikan sebaya

Gambar 1. Diagram alur pengumpulan sampel penelitian

Pendidikan kesehatan reproduksi diberikan selama dua minggu pada kelompok perlakuan. Pada awal dan akhir dari pendiddikan kesehatan reproduksi dilakukan pre-test dan post-test dengan menggunakan kuesioner. Pretest dan post-test berupa pertanyaan tertutup tentang kesehatan reproduksi sejumlah 50 buah (pertanyaan tentang pertumbuhan dan perkembangan sebanyak 26 buah, pertanyaan tentang IMS sebanyak 24 buah) yang terdiri dari 31 pertanyaan favorable (jawaban benar mendapat skor 1 dan jawaban salah mendapatkan skor 0) dan 19 pertanyaan unfavorable (jawaban benar mendapat skor 0 dan jawaban salah mendapatkan skor 1). Skor pengetahuan $=$ total skor $\times 2$. Setelah data terkumpul dan dibersihkan selanjutnya dilakukan analisis data. Tahap pertama dalam analisis data adalah menguji tingkat sebaran atau distribusi data menggunakan uji saphiro-wilk. Jika data terdistribusi normal, data akan diuji menggunakan tes parametrik yaitu independent t-test untuk mengetahui perbedaan pengetahuan pendidikan pada kelompok kasus dan kontrol sedangkan paired t-test untuk mengetahui perbedaan pengetahuan kesehatan reproduksi sebelum dan sesudah intervensi pendidikan sebaya pada kedua kelompok. Jika data tidak terdistribusi normal, data akan diuji menggunakan tes non parametrik yaitu mannwhitney dan wilcoxon signed-rank test.

\section{HASIL}

Jumlah sampel minimal yang dibutuhkan untuk masing-masing kelompok adalah 13 orang. Namun, saat pertemuan pertama umtuk kelompok perlakuan yang hadir dan bersedia menjadi sampel ada 17 orang, sehingga untuk kelompok kontrol juga di ambil 17 orang. Pada kelompok perlakuan terdapat 4 sampel yang drop out karena tidak hadir saat pendidikan kesehatan reproduksi dan post-test, sehingga total sampel yang terkumpul pada kelompok kasus adalah 13 orang. Drop out juga terjadi pada kelompok kontrol, jumlah drop out di kelompok kontrol 1 orang sehingga total sampel pada kelompok kontrol adalah 16 orang.

Berdasarkan hasil penelitian diperoleh gambaran bahwa sebagian besar responden pada kelompok perlakuan berjenis kelamin perempuan $(76,92 \%)$ sedangkan di kelompok kontrol berjenis kelamin laki-laki $(56,25 \%)$. Rata-rata umur responden (perlakuan dan kontrol) adalah 17 tahun. Pendidikan responden pada kelompok perlakuan $(76,92 \%)$ dan kontrol $(56,25 \%)$ adalah tinggi seperti yang ditunjukkan pada tabel 1 berikut.

Tabel 1. Distribusi Karakteristik Responden menurut Jenis Kelamin, Umur, Pendidikan Terakhir

\begin{tabular}{|c|c|c|c|c|c|c|c|}
\hline \multirow{2}{*}{ Karakteristik Sampel } & \multicolumn{3}{|c|}{ Perlakuan } & \multicolumn{3}{|c|}{ Kontrol } & \multirow[t]{2}{*}{ p value } \\
\hline & $\mathbf{n}$ & $\%$ & Mean & n & $\%$ & Mean & \\
\hline \multicolumn{8}{|l|}{ Jenis Kelamin } \\
\hline Laki-laki & 3 & 23,08 & & 9 & 56,25 & & \multirow{2}{*}{0,07} \\
\hline Perempuan & 10 & 76,92 & & 7 & 43,75 & & \\
\hline Umur & 13 & - & 17,77 & 16 & - & 17,31 & 0,55 \\
\hline \multicolumn{8}{|l|}{ Pendidikan Terakhir } \\
\hline Tinggi & 10 & 76,92 & & 9 & 56,25 & & \multirow{2}{*}{0,24} \\
\hline Rendah & 3 & 23,08 & & 7 & 43,75 & & \\
\hline
\end{tabular}


Septa, et al. Pengaruh Pendidikan Sebaya Terhadap Pengetahuan Kesehatan Reproduksi Remaja di Karang Taruna Kabupaten Banyuwangi

Sebagai suatu studi eksperimen terdapat dua kelompok yang akan dibandingkan yaitu kelompok perlakuan dan kelompok control. Maka faktor kesetaraan antara kedua kelompok tersebut menjadi penting. Oleh karena itu, dilakukan uji kesetaraan (menggunakan uji $\chi^{2}$ ) untuk melihat kedua kelompok tersebut layak dibandingkan atau tidak dengan cara melakukan kontrol terhadap beberapa variabel. Hasil penelitian menujukkan bahwa tidak terdapat perbedaan jenis kelamin, umur dan tingkat pendidikan antara kelompok perlakuan dan
JPH RECODE Maret 2018; 1 (2) : 80:88 http://e-journal.unair.ac.id/JPHRECODE

kontrol ( $\mathrm{p}=0,07 ; 0,55$; dan 0,24$)$, sehingga kedua kelompok layak untuk diperbandingkan (Tabel 1). Hasil penelitian (Tabel 2) menunjukkan bahwa rata-rata pengetahuan kesehatan reproduksi sebelum dan sesudah pendidikan sebaya pada kelompok perlakuan $(73,85$ dan $82,31)$ lebih tinggi daripada kelompok kontrol $(60,63$ dan 69,75) yang tidak mendapat pendidikan sebaya. Perbedaan tersebut diuji secara statistik dan terbukti berbeda secara signifikan $(\mathrm{p}=0,04$ dan $\mathrm{p}=0,00)$.

Tabel 2. Rata-rata Pengetahuan Kesehatan Reproduksi Sebelum dan Sesudah Pelatihan

\begin{tabular}{lllccccc}
\hline & & n & Mean & SD & Min & Max & p value \\
\hline \multirow{2}{*}{ Sebelum } & Perlakuan & 13 & 73,85 & 13,75 & 44 & 90 & 0,04 \\
& Kontrol & 16 & 60,63 & 18,43 & 22 & 80 & \\
\hline \multirow{2}{*}{ Sesudah } & Perlakuan & 13 & 82,31 & 9,59 & 56 & 92 & 0,00 \\
& Kontrol & 16 & 69,75 & 9,88 & 50 & 88 & \\
\hline
\end{tabular}

Secara statistik pengetahuan sebelum perlakuan antara kedua kelompok memang berbeda (Tabel 3) namun dilihat dari rata-rata skor pengetahuan yang diperoleh kedua kelompok termasuk dalam pengetahuan yang rendah. Hal ini berarti remaja pada kedua kelompok belum mempunyai pengetahuan secara menyeluruh tentang kesehatan reproduksi.
Pengetahuan setelah perlakuan antara kedua kelompok juga berbeda (tabel 3). Pengetahuan post-test pada kelompok perlakuan lebih tinggi daripada kelompok kontrol. Pengetahuan setelah perlakuan antara kedua kelompok juga berbeda. Pengetahuan post-test pada kelompok perlakuan lebih tinggi daripada kelompok kontrol $(\mathrm{p}=0,04$ dan $\mathrm{p}=0,01$ ).

Tabel 3. Hasil Uji Beda Pengetahuan Kesehatan Reproduksi pada Kelompok Perlakuan dan Kontrol

\begin{tabular}{lccccc}
\hline & \multicolumn{2}{c}{ Sebelum } & \multicolumn{2}{c}{ Sesudah } & \multirow{2}{*}{ p value } \\
\cline { 1 - 5 } Kelompok & Mean & SD & Mean & SD & \\
\hline Perlakuan & 73,85 & 13,75 & 82,31 & 9,59 & 0,04 \\
Kontrol & 60,63 & 18,43 & 69,75 & 9,88 & 0,01 \\
\hline
\end{tabular}

Perbedaan rata-rata pengetahuan memang bermakna diantara kedua kelompok (Tabel 4), namun jika dilihat dari perbedaan peningkatan nilai responden dari pre-test ke post-test antara kedua kelompok maka tidak bermakna $(\mathrm{p}=0,89)$. Rata-rata peningkatan pengetahuan pada kelompok perlakuan sebesar 8,45 sedangkan pada kelompok kontrol sebesar 9,13. Untuk melihat sejauh mana pengaruh pendidikan kelompok sebaya terhadap perubahan pengetahuan remaja maka dilakukan kontrol terhadap variabel umur, jenis kelamin, dan Pendidikan. Untuk variabel kontrol (jenis kelamin, umur dan pendidikan) juga menunjukkan tidak ada perbedaan pada kedua kelompok $(\mathrm{p}=0,51 ; \mathrm{p}=0,46 ; \mathrm{p}=0,08)$. 
Tabel 4. Perbedaan Mean Perubahan Pengetahuan Berdasarkan Variabel Utama Dan Kontrol

\begin{tabular}{lccccc}
\hline & n & Mean & SD & p value & CI 95\% \\
\hline Kelompok & & & & & \\
$\quad$ Perlakuan & 13 & 8,45 & 13,84 & 0,89 & $0,10-16,82$ \\
$\quad$ Kontrol & 16 & 9,13 & 13,37 & & $2,00-16,25$ \\
\hline Jns Kelamin & 12 & 6,83 & 14,02 & 0,51 & $-2,08-15,74$ \\
$\quad$ Laki-laki & 17 & 10,24 & 13,07 & & $3,51-16,96$ \\
$\quad$ Perempuan & & & & & \\
\hline Umur & 25 & 8,08 & 13,29 & 0,46 & $2,59-13,56$ \\
$\quad 15-19$ & 4 & 13,5 & 14,64 & & $-9,79-36,79$ \\
$\quad 20-24$ & 19 & 6,42 & 12,41 & 0,19 & $0,44-12,40$ \\
\hline Pendidikan Terakhir & 10 & 13,4 & 14,49 & & $3,04-23,76$ \\
$\quad$ Tinggi & & &
\end{tabular}

\section{PEMBAHASAN}

Masa remaja merupakan masa kritis dalam perkembangan perilaku individu. Remaja biasanya mempunyai keinginan untuk mencoba perilaku baru yang modern dan kekinian. Perilaku tersebut tidak selalu mengarah pada kebaikan tetapi juga membawa risiko pada kesehatan. Perilaku remaja dapat dipengaruhi oleh tingkat pendidikan, tingkat pendidikan tersebut dapat mempengaruhi kemampuan dan pengetahuan seseorang dalam penerapan hidup sehat (Wulandari, 2009). Wiknjosastro (2006) berpendapat bahwa pendidikan formal mampu menghasilkan perilaku, tetapi pada beberapa orang tingkat pendidikan tidak mempengaruhi pengetahuan dan sikap. Pengetahuan dan sikap lebih dipengaruhi oleh lingkungan yang diterima oleh individu.

Salah satu bentuk lingkungan yang dapat mempengaruhi pengetahuan adalah pendidikan non-formal. Pendidikan non-formal dapat diperoleh dari keluarga, organisasi, dan masyarakat (WHO, 2011). Salah satu contoh pendidikan non-formal adalah pendidikan sebaya. Pendidikan sebaya adalah kegiatan yang bertujuan untuk mengembangkan pengetahuan, sikap dan tindakan sekelompok orang yang dilaksanakan antar kelompok sebaya dan dipandu oleh seorang fasilitator yang berasal dari kelompok itu sendiri (Depkes R.I, 2008). Dalam penelitian ini dilakukan uji kesetaraan. Uji kesetaraan dalam penelitian eksperimental dapat menghindari ancaman terhadap validasi internal dan eksternal. Penelitian ini sejalan dengan penelitian yang dilakukan oleh Swandewi et al (2006) yang menyatakan bahwa karakteristik responden menurut umur dan tingkat responden pada kelompok perlakuan dan kontrol adalah sama ( $\mathrm{p}>0,05)$.

Perbedaan pengetahuan kesehatan reproduksi sebelum perlakuan antara kelompok perlakuan dan kontrol seharusnya tidak terjadi. Penelitian ini berbeda dengan penelitian yang telah dilakukan oleh Oktarina et al (2017) yang menyatakan bahwa pengetahuan awal kedua kelompok adalah sama $(\mathrm{p}>0,05)$. Seperti telah dijelaskan sebelumnya bahwa syarat penelitian eksperimen adalah homogenitas pada masingmasing kelompok. Penyetaraan kelompok awal antara kelompok eksperimen dan kelompok kontrol dapat digunakan untuk mengendalikan bias pada penelitian eksperimen. Peneliti telah menetapkan kriteria inklusi untuk sampel namun pada penelitian ini terjadi perbedaan pengetahuan awal karena pada kelompok perlakuan kemungkinan memiliki tingkat kecerdasan (IQ) yang lebih tinggi daripada kelompok kontrol. Penerapan kontrol terhadap IQ sulit dilakukan. Pada penelitian ini tidak melakukan penyamaan terhadap IQ pada kedua kelompok. Penyebab lainnya adalah adanya pengalaman subjek dalam memperoleh sumber informasi lain mengenai kesehatan reproduksi sebelum pendidikan sebaya ini dilaksanakan.

Kelompok perlakuan memiliki nilai posttest lebih tinggi dibandingkan kelompok kontrol. Penelitian ini sejalan dengan penelitian yang dilakukan oleh Mubaroq et al (2014) yang 
Septa, et al. Pengaruh Pendidikan Sebaya Terhadap Pengetahuan Kesehatan Reproduksi Remaja di Karang Taruna Kabupaten Banyuwangi

menunjukkan perbedaan pengetahuan sesudah perlakuan pada kelompok perlakuan dan kontrol $(\mathrm{p}=0,001)$ dimana rata-rata pengetahuan kelompok perlakuan lebih tinggi dibandingkan dengan siswa pada kelompok kontrol. Perbedaan tersebut terjadi karena adanya perlakuan berupa pendidikan sebaya pada kelompok perlakuan.

Perlakuan yang diberikan selama dua minggu memberikan hasil yang diharapkan. Hasil penelitian Oktarina, et al (2017) menunjukkan bahwa pelaksanaan pendidikan yang dilakukan selama dua minggu dimana setiap minggu dilakukan dua kali pertemuan ddengan waktu sekitar lima jam dapat meningkatkan pengetahuan kesehatan reproduksi pad kelompok perlakuan $(\mathrm{p}<0,001)$. Proses pendidikan sebaya tentang kesehatan reproduksi yang dilakukan selama intervensi adalah diskusi peorangan, diskusi kelompok kecil atau besar dan motivasi pada perorangan atau kelompok. Pendidikan tersebut dapat meningkatkan pengetahuan remaja terhadap pentingnya kesehatan reproduksi, sehingga remaja dapat bertanggung jawab atas keputusan mengenai perilaku seksualnya. United Nations Educational Scientific and Cultural Organization tahun 2009 mengemukakan bahwa pendidikan tersebut dapat meningkatkan pengetahuan, keterampilan, dan nilai untuk membuat keputusan terhadap perilaku seksual (United Nations Educational Scientific And Cultural Organization, 2010).

Penelitian ini sejalan dengan penelitian yang telah dilakukan oleh Swandewi, et al (2006) dengan nilai $\mathrm{p}>0,05$ yang menunjukkan bahwa nilai pretest ke posttest 1 antara kedua kelompok tidak bermakna. Walupun peningkatan pengetahuan antara kedua kelompok tidak berbeda $(\mathrm{p}=0,89)$ secara statistik namum pada masing-masing kelompok terjadi peningkatan pengetahuan.

Peningkatan pengetahuan pada kelompok perlakuan $(8,45$ dan $\mathrm{p}=0,04)$ menunjukkan bahwa pendidikan kesehatan reproduksi dengan pendidik sebaya dapat meningkatkan pengetahuan dan mempertahankan retensi pengetahuan karena proses pendidikan kesehatan tersebut disampaikan secara kontinyu. Medley et al (2009) menyatakan bahwa kegiatan pendidikan kesehatan sebaya yang dilakukan dimana saja, kapan saja, dalam suasana informal, menggunakan bahasa yang sama, dalam kelompok sebaya yang mempunyai hubungan yang akrab dapat menghasilkan interaksi setiap saat serta meningkatkan pengetahuan. Pendidikan sebaya juga melibatkan peserta secara aktif sehingga pengetahuan yang diperoleh lebih diingat oleh peserta dan lebih bertahan lama. Peningkatan pengetahuan juga dapat terjadi karena sebelumnya kelompok perlakuan sudah mengetahui kalau akan diuji maka mereka belajar terlebih dahulu.

Pada kelompok kontrol, peningkatan pengetahuan $(9,13$ dan $\mathrm{p}=0,01)$ dapat terjadi karena jarak pengambilan pretest dan posttest terlalu dekat yaitu satu minggu dikarenakan penulis mengalami kesulitan dalam mengumpulkan sampel. Selang waktu yang ideal untuk melaksanakan pretest dan posttest adalah 15-30 hari. Tujuannya adalah menghindarkan subjek yang masih mengingat/pernah melakukan hal yang sama pada saat pretest. Makin pendek jarak waku antara uji awal dan uji akhir, makin besar terjadinya pengaruh faktor retensi. Jika jarak waktu terlalu dekat maka responden juga masih mengingat jawaban pertama (Shadish dan Cook, 2002). Penyebab lain dari peningkatan pengetahuan pada kelompok kontrol adalah mereka sudah tahu kalau mereka diteliti dan akan diteliti kembali, sehingga ada kemungkinan mereka mempersiapkan diri ketika akan dilakukan post-test. Walaupun kelompok kontrol tidak memperoleh perlakuan berupa pendidikan kesehatan namun mereka dapat mengakses informasi melalui televisi, koran maupun internet.

Keterbatasan pada penelitian ini adalah tidak melakukan kontrol terhadap IQ responden pada kedua kelompok. Selain itu jarak pengambilan pre-test dan post-test pada kelompok kontrol terlalu dekat yaitu seminggu serta pada kedua kelompok telah mengetahui bahwa mereka akan di test kembali.

\section{KESIMPULAN}

Berdasarkan hasil penelitian dapat disimpulkan bahwa ada perbedaan pengetahuan kesehatan reproduksi sebelum dan sesudah antara kelompok pendidikan sebaya dan kelompok kontrol pada remaja karang taruna di Desa Tamansari Kecamatan Licin serta ada perbedaan pengetahuan kesehatan reproduksi 
Septa, et al. Pengaruh Pendidikan Sebaya Terhadap Pengetahuan Kesehatan Reproduksi Remaja di Karang Taruna Kabupaten Banyuwangi

setelah dan sebelum pendidikan sebaya pada kelompok pendidikan sebaya dan kelompok kontrol remaja karang taruna di Desa Tamansari Kecamatan Licin. Penelitian juga menunjukkan tidak ada pengaruh pendidikan terhadap peningkatan pengetahuan remaja karang taruna di Desa Tamansari Kecamatan Licin.

\section{SARAN}

Pendidikan sebaya sebaiknya dilakukan pada kelompok pendidikan yang sejenis sehingga tidak terjadi kesenjangan dalam penyampaian materi, jarak melakukan pretest dan posttest pada kedua kelompok harusnya sama untuk menghindari faktor retensi. Hari pelaksanaan intervensi diperpanjang sehingga waktu pelaksanaan perhari tidak terlalu lama. Waktu yang terlalu lama membuat responden jenuh.

\section{DAFTAR PUSTAKA}

Aisah, S., Sahar, J., Hastono, S. 2010. Pengaruh Edukasi Kelompok Sebaya Terhadap Perubahan Perilaku Pencegahan Anemia Gizi Besi Pada Wanita Usia Subur. Skripsi, Universitas Muhammadiyah, Semarang.

Aryani. 2010. Kesehatan Remaja Problem dan Solusinya. Jakarta: Salemba Medika.

Badan Kependudukan dan Keluarga Berencana Nasional (BKKBN). 1999. Baseline Survey of Young Adult Reproductive Welfare in Indonesia, 1988/1999.

Badan Pusat Statistik dan Macro International. 2007. Survei Kesehatan Reproduksi Remaja Indonesia 2007. Jakarta: Badan Pusat Statistik dan Macro International.

BPPKB Banyuwangi. 2015. Perkawinan Dini Merangkak Naik. Banyuwangi: BPPKB. Diakses dari: http://bppkb.banyuwangikab.go.id/page/ne ws/perkawinan-dini-merangkak-naik.

Depkes R.I. 2008. Program Kesehatan Reproduksi dan Pelayanan Intergratif di

Tingkat Pelayanan Dasar. Jakarta: Departemen Kesehatan.

Kecamatan Licin. 2014. Profil Desa Taman Sari. Banyuwangi: Kecamatan Licin.

Kemenkes RI. 2010. Riset Kesehatan Dasar (Riskesdas) Nasional 2010.

Kemenkes RI. 2012. Survei Demografi dan Kesehatan Indonesia 2012, Laporan
JPH RECODE Maret 2018; 1 (2) : 80:88 http://e-journal.unair.ac.id/JPHRECODE

Pendahuluan. Jakarta: Kementerian Kesehatan RI.

Kementerian Kesehatan Republik Indonesia. 2013. Basic Health Research Report, Jakarta: Health Research And Development Agency, Ministry of Health.

Medley, A. et al. 2009. Effectiveness of peer education interventions for HIV prevention in developing countries: A systematic review and meta-analysis. AIDS Education and Prevention, 21(3), pp. 181-206. doi: 10.1521/aeap.2009.21.3.181.

Mubaroq, et al 2014. Efektivitas Pendidikan kesehatan dengan Penerapan The Health Belief Model terhadap Pengetahuan Keluarga tentang Diare. Jom PSIK, 1(2), pp. 1-9.

Oktarina, J., Marono, H. M. dan Purnomo, W. 2017. Pengaruh Pendidikan Kesehatan Reproduksi oleh Sebaya Terhadap Pengetahuan dan Sikap dalam Pencegahan Seks Pranikah di SMAN 1 Sukamara, Kabupaten Sukamara, Kalimantan Tengah. Buletin Penelitian Sistem Kesehatan, 20(1), pp. 26-33. doi: 10.22435/hsr.v20i1.6180.26-33.

Pemkab Banyuwangi. 2015. Bupati Minta Warga Banyuwangi di Bali Jaga Citra Daerah.

Presiden Republik Indonesia. 2009. UU RI No 36 Tentang Kesehatan.

Shadish, W. R. dan Cook, T. D. 2002. And Quasi-Experimental For Generalized Designs Causal Inference fr Experiments Causal Generalized lnference. Handbook of industrial and organizational psychology.

Swandewi, et al. 2006. Efektivitas Promosi Kesehatan dengan Peer Education. Berita Kedokteran Masyarakat, 22(3), pp. 128134.

United Nations Educational Scientific And Cultural Organization. 2010. Globalization And Women's Vulnerabilities To Hiv And Aids, France, Division For Gender Equality, Unesco.

WHO. 2011. The sexual and reproductive health of younger adolescents: research issues in developing countries: background paper for consultation. Geneva: WHO. 
Septa, et al. Pengaruh Pendidikan Sebaya Terhadap

Pengetahuan Kesehatan Reproduksi Remaja di Karang

Taruna Kabupaten Banyuwangi
JPH RECODE Maret 2018; 1 (2) : 80:88

http://e-journal.unair.ac.id/JPHRECODE

Wiknjosastro, H. 2006. Ilmu Kebidanan. Jakarta: Yayasan Bina Pustaka Sarwono Prawirohardjo.

Wulandari, A. 2009. Hubungan antara Faktor Lingkungan dan Faktor Sosiodemografi dengan Kejadian Diare pada Balita di Desa Belimbing Kecamatan Sambirejo Kabupaten Seragen Tahun 2009. Skripsi, Universitas Muhammadiyah, Surakarta.

Zumala dan Alika. 2014. Penguatan Kesehatan Reproduksi Di Komunitas Muslim Kabupaten Banyuwangi. Jurnal Pendidikan, Komunikasi, dan Pemikiran Hukum Islam, 6(1), pp. 190-208. 